\title{
Nationwide Study of Drug Resistance Mutations in HIV-1 Infected Individuals under Antiretroviral Therapy in Brazil
}

\author{
Ana Santos-Pereira ${ }^{1,2}$, Vera Triunfante ${ }^{1,2}$, Pedro M. M. Araújo ${ }^{1,2}$, Joana Martins ${ }^{1,2}$, Helena Soares ${ }^{3,4}$, \\ Eva Poveda 5 (D) Bernardino Souto ${ }^{1,2,6}$ and Nuno S. Osório ${ }^{1,2, *(\mathbb{D})}$ \\ 1 Life and Health Sciences Research Institute (ICVS), School of Medicine, University of Minho, \\ 4710-057 Braga, Portugal; anaapspereira@gmail.com (A.S.-P.); vera.triunfante@gmail.com (V.T.); \\ id5827@alunos.uminho.pt (P.M.M.A.); joana_smar@hotmail.com (J.M.); bernardino@ufscar.br (B.S.) \\ 2 ICVS/3B's-PT Government Associate Laboratory, 4710-057 Braga, Portugal \\ 3 Human Immunobiology and Pathogenesis Laboratory, 1150-082 Lisbon, Portugal; helena.soares@nms.unl.pt \\ 4 CEDOC-Chronic Diseases Research Center, NOVA Medical School, Faculdade de Ciências Médicas, \\ NOVA University of Lisbon, 1150-082 Lisbon, Portugal \\ 5 Group of Virology and Pathogenesis, Galicia Sur Health Research Institute (IIS Galicia Sur)-Complexo \\ Hospitalario Universitario de Vigo, SERGAS-UVigo, 36213 Vigo, Spain; Eva.Poveda.Lopez@sergas.es \\ 6 Department of Medicine, Federal University of São Carlos, São Paulo 13565-905, Brazil \\ * Correspondence: nosorio@med.uminho.pt; Tel.: +351-253-604904
}

\section{check for} updates

Citation: Santos-Pereira, A.; Triunfante, V.; Araújo, P.M.M.; Martins, J.; Soares, H.; Poveda, E.; Souto, B.; Osório, N.S. Nationwide Study of Drug Resistance Mutations in HIV-1 Infected Individuals under Antiretroviral Therapy in Brazil. Int. J. Mol. Sci. 2021, 22, 5304. https:// doi.org/10.3390/ijms22105304

Academic Editors: Ashraf S. Yousif and Larance Ronsard

Received: 22 April 2021

Accepted: 13 May 2021

Published: 18 May 2021

Publisher's Note: MDPI stays neutral with regard to jurisdictional claims in published maps and institutional affiliations.

Copyright: (c) 2021 by the authors. Licensee MDPI, Basel, Switzerland. This article is an open access article distributed under the terms and conditions of the Creative Commons Attribution (CC BY) license (https:// creativecommons.org/licenses/by/ $4.0 /)$.

\begin{abstract}
The success of antiretroviral treatment (ART) is threatened by the emergence of drug resistance mutations (DRM). Since Brazil presents the largest number of people living with HIV (PLWH) in South America we aimed at understanding the dynamics of DRM in this country. We analyzed a total of 20,226 HIV-1 sequences collected from PLWH undergoing ART between 20082017. Results show a mild decline of DRM over the years but an increase of the K65R reverse transcriptase mutation from $2.23 \%$ to $12.11 \%$. This increase gradually occurred following alterations in the ART regimens replacing zidovudine (AZT) with tenofovir (TDF). PLWH harboring the K65R had significantly higher viral loads than those without this mutation $(p<0.001)$. Among the two most prevalent HIV-1 subtypes (B and C) there was a significant $(p<0.001)$ association of K65R with subtype C (11.26\%) when compared with subtype B (9.27\%). Nonetheless, evidence for K65R transmission in Brazil was found both for C and B subtypes. Additionally, artificial neural networkbased immunoinformatic predictions suggest that K65R could enhance viral recognition by HLA-B27 that has relatively low prevalence in the Brazilian population. Overall, the results suggest that tenofovir-based regimens need to be carefully monitored particularly in settings with subtype $\mathrm{C}$ and specific HLA profiles.
\end{abstract}

Keywords: HIV-1; drug resistance mutations; K65R; antiretroviral treatment failure; tenofovir; Brazilian cohort study

\section{Introduction}

According to the Joint United Nations Programme on HIV / AIDS (UNAIDS), 690,000 individuals died in 2019 of human immunodeficiency virus (HIV) infection-related causes. Although the global number of new infections (1.7 million) has been reduced by $23 \%$, since 2010, Latin America has presented a 21\% increase. Particularly, Brazil experienced an increase of $17 \%$, with 48,000 new reported infections and 14,000 acquired immunodeficiency syndrome (AIDS)-related deaths, in the same year [1].

Antiretroviral therapy (ART) significantly improves patients' survival, increasing life expectancy and quality [2-4]. Furthermore, it plays a relevant role in the prevention of HIV-1 transmission in the population [5-8]. However, the emergence of drug resistance mutations (DRM) represents a major threat for the continued control of HIV replication, and consequent potential increase in the transmission of viral strains with DRM $[9,10]$. The prevalence of DRM can greatly vary between different geographical areas, depending 
on several factors, ranging from study design to the sociodemographic characteristics of the population and most prevalent HIV-1 subtypes [9,11-15]. With a total area as vast as 8.51 million $\mathrm{km}^{2}$, different DRM rates have also been found in distinct Brazilian geographic regions $[9,12,16-20]$.

In 1996, Brazil became the first middle-income country to ensure free access to ART to all individuals infected with HIV, through the public Unified Health System [21,22]. Currently, 69\% of the people living with HIV are under ART [1]. Initial ART regimens in Brazil consist of a combination of three drugs, comprising two NRTIs and a third of different ART class: a non-nucleoside reverse transcriptase inhibitor (NNRTI), a protease inhibitor (PI) or an integrase inhibitor (INSTI) [21]. Although pre-treatment testing for DRM in the reverse transcriptase (RT) and protease (PR) has been widely recommended by the International Antiviral Society-USA, the US Department of Health and Human Services and the European AIDS Clinical Society, among others, viral genotyping and resistance testing are preferably performed in Brazil after 6 months of treatment failure [21,23-25]. After 2013, pre-treatment genotyping was also indicated by the Brazilian Government in the following scenarios: Mycobacterium tuberculosis (Mtb) co-infection, pregnant woman, children and new diagnoses with a sexual partner under ART [21,22]. Importantly, Brazil is the only country in South America that provides pre-exposure prophylaxis (PrEP) through the public health system [1,21].

Among the surveillance drug-resistance mutations (SDRM) [26], K65R is commonly associated with tenofovir (TDF) resistance and different prevalence rates of this mutation have been reported in several Brazilian cities $[11,17,27]$. It was also associated with resistance to other reverse transcriptase inhibitors (NRTIs), but it confers increased susceptibility to zidovudine (AZT) [28-33]. K65R is acquired in B and several other HIV-1 subtypes by the $\mathrm{AAA} \rightarrow$ AGA substitution while in subtype $C$ the involved substitution is $A A G \rightarrow A G G$, which has been associated with higher probability of $C$ subtype viruses to acquire this mutation $[31,32,34,35]$.

The relevant reforms made in ART protocols in Brazil during the last decades, promoting the preferential use TDF containing schemes in the absence of universal HIV-1 genotyping, raised the hypothesis that the HIV DRM profile could have changed, bringing novel treatment obstacles and clinical implications. To test this hypothesis, we retrospectively studied data from 20,226 HIV-1 infected and ART-treated individuals from all regions of Brazil, from 2008 to 2017. We used statistical and genome sequence analysis to understand, at an unprecedented scale in Brazil, the dynamics of evolution of the HIV-1 drug resistance profiles. Additionally, we also relied on immunoinformatics to investigate factors possible underlying treatment failure and transmission of DRM.

\section{Results}

\subsection{Characterization of the Study Population}

The study comprised a total of 20,226 HIV-1 infected individuals, with a HIV-1 sequence genotyped between 2008 and 2017, on ART treatment, from which $44.3 \%(n=8962)$ were female and $55.7 \%(n=11,263)$ male. The main characteristics of the study population are shown in Table 1 . The median age was $39.55( \pm 12.71)$ years (yrs). Most of the individuals were were between 30 and 49 yrs old (61.44\%), from the State of São Paulo (21.98\%; $n=4445)$, followed by the States of Rio Grande do Sul $(11.96 \% ; n=2419)$, Minas Gerais $(9.29 \% ; n=1878)$, Rio de Janeiro $(9.20 \% ; n=1861)$ and Paraná $(7.94 \% ; n=1606)$. The geographic frequency distribution for PLWH in the study population was in agreement with the official Brazilian HIV-1 prevalence reports [36]. These patients were on ART, in average, for $2.98( \pm 2.96)$ yrs and the most common treatment schemes combinations were: lamivudine (3TC)/efavirenz (EFV)/TDF $(21.38 \% ; n=4324), 3 \mathrm{TC} / \mathrm{AZT} / \mathrm{EFV}(19.79 \% ; n=4003)$, 3TC/AZT/low-dose ritonavir-boosted lopinavir (LPV) $(11.16 \% ; n=2258)$, 3TC / LPV /TDF $(8.24 \% ; n=1666)$ and 3TC/atazanavir $(\mathrm{ATV}) /$ ritonavir $(\mathrm{RTV}) / \mathrm{TDF}(6.70 \% ; n=1355)$. 
Table 1. Characterization of the study population.

\begin{tabular}{|c|c|c|c|}
\hline & HIV-1 ${ }^{+}$Individuals & Female & Male \\
\hline All ages & $20,226(100.00 \%)$ & $8962(44.3 \%)$ & $11,263(55.7 \%)$ \\
\hline$<1$ yrs old & $64(0.32 \%)$ & $30(0.15 \%)$ & $34(0.17 \%)$ \\
\hline $2-9$ yrs old & $364(1.80 \%)$ & $200(0.99 \%)$ & $164(0.81 \%)$ \\
\hline $10-17$ yrs old & $840(4.15 \%)$ & $426(2.11 \%)$ & $414(2.05 \%)$ \\
\hline $18-30$ yrs old & $2443(12.08 \%)$ & $1201(5.94 \%)$ & $1242(6.14 \%)$ \\
\hline $30-49$ yrs old & $12,426(61.44 \%)$ & $5390(26.65 \%)$ & $7036(34.79 \%)$ \\
\hline $50-79$ yrs old & $4074(20.14 \%)$ & $1709(8.45 \%)$ & $2364(11.69 \%)$ \\
\hline$>80$ yrs old & $15(0.07 \%)$ & $6(0.03 \%)$ & $9(0.04 \%)$ \\
\hline Age (av. yrs \pm std) & $39.55 \pm 12.71$ & $38.67 \pm 13.15$ & $40.25 \pm 12.31$ \\
\hline Treatment (av. yrs \pm std) & $2.98 \pm 2.96$ & $3.06 \pm 2.96$ & $2.92 \pm 2.95$ \\
\hline Birth Federative Unit & HIV-1 ${ }^{+}$individuals & Treatment Scheme & HIV-1 ${ }^{+}$individuals \\
\hline São Paulo & $4445(21.98 \%)$ & 3TC,EFV,TDF & $4324(21.38 \%)$ \\
\hline Rio Grande do Sul & 2419 (11.96\%) & 3TC,AZT,EFV & 4003 (19.79\%) \\
\hline Minas Gerais & $1878(9.29 \%)$ & 3TC,AZT,LPV & $2258(11.16 \%)$ \\
\hline Rio de Janeiro & $1861(9.20 \%)$ & 3TC,LPV,TDF & $1666(8.24 \%)$ \\
\hline Paraná & 1606 (7.94\%) & 3TC,ATV,RTV,TDF & $1355(6.70 \%)$ \\
\hline Others & $8017(39.64 \%)$ & Others & $6620(32.73 \%)$ \\
\hline
\end{tabular}

av. average; std, standard deviation; yrs, years; HIV-1 ${ }^{+}, \mathrm{HIV}-1$ infected.

\subsection{Prevalence of Surveillance Drug-Resistance Mutations}

We evaluated the presence of surveillance drug-resistance mutations (SDRM) in the study population, including SDRM found isolated or in combinations in the same virus, and uncovered an overall prevalence of $84.10 \%(n=17,011)$. SDRM were mostly found at the RT $(83.24 \% ; n=16,836)$ and included 13,845 sequences with NRTI DRM and 11,720 sequences with NNRTI DRM. The most common SDRM (Figure 1, Supplementary Table S2) were the substitutions in RT amino acids M184V $(65.53 \%, n=13,265), \mathrm{K} 103 \mathrm{~N}(40.20 \%, n=8738)$, and M41L $(17.21 \%, n=3480)$. SDRM in PR were found in $5021(24.82 \%)$ sequences and the more frequent were V82A $(9.99 \%, n=2021), \mathrm{M} 46 \mathrm{I}(9.58 \%, n=1938)$, and $\mathrm{I} 54 \mathrm{~V}(8.50 \%, n=1719)$.

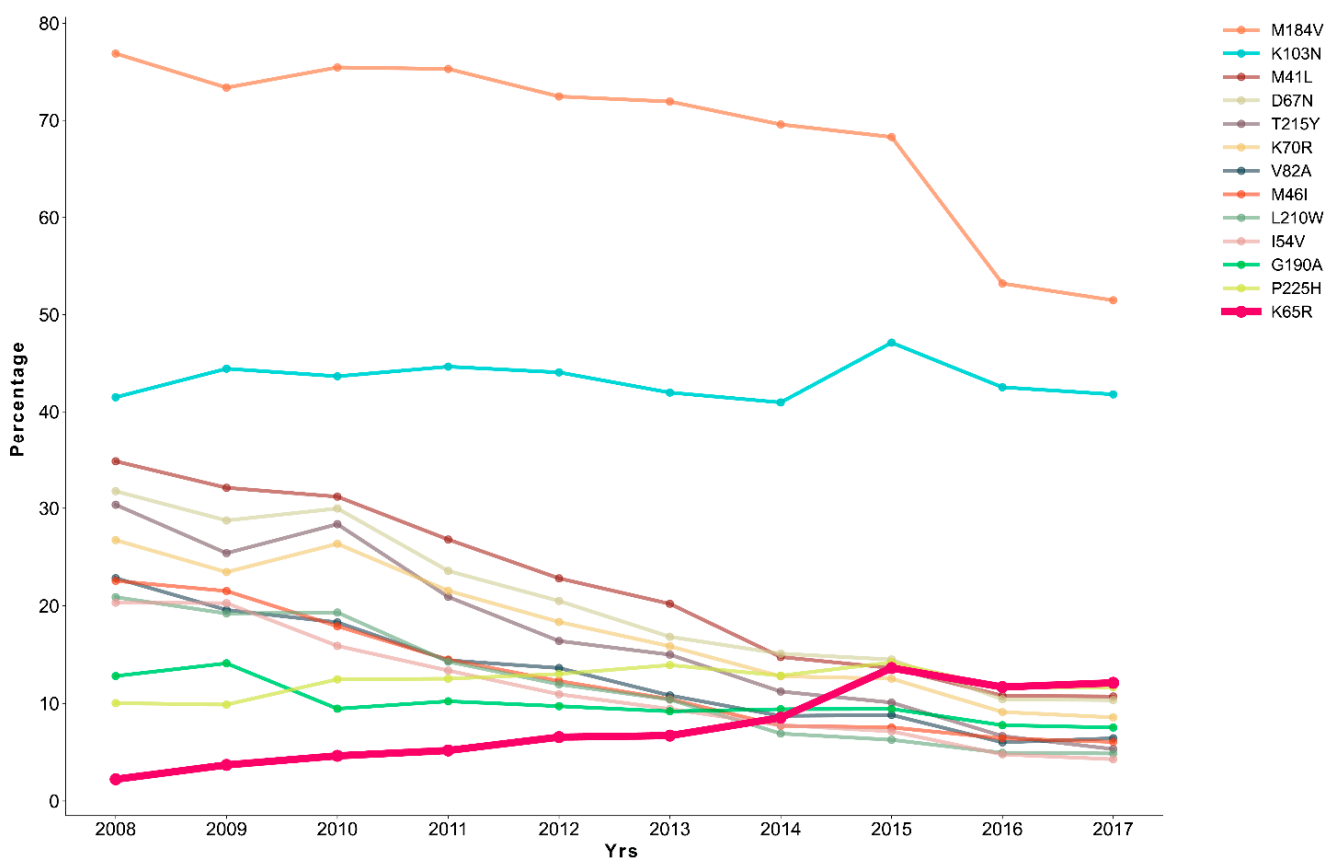

Figure 1. Surveillance drug-resistance mutations prevalence in HIV-1 RT and PR through the yrs 2008 to 2017. Percentage of individuals infected with a viral strain that presented one of the most common SDRM in the different yrs. 


\subsection{A Gradual Alteration on the Prevalence of Surveillance Drug-Resistance Mutations}

To investigate the temporal dynamics and evolution of the SDRM landscape in the study population we evaluated yearly SDRM prevalence from 2008 until 2017. The most common mutation across the years was M184V (Figure 1), notwithstanding a decreasing trend and a significant decrease between $2015(68.29 \%, n=1874)$ and $2016(53.21 \%, n=2684)$ $(p<0.001)$ (Table 2). Similarly, all the other 10 most frequent SDRM followed a decreasing trend along the years with the remarkable exception for K65R and K103N (Figure 1). K103N remained stable in the studied period. While the prevalence of viruses harboring K103N increased between $2014(40.97 \%, n=1180)$ and $2015(47.12 \%, n=1293 ; p<0.001)$ this was accompanied with a significant decrease in $2016(42.53 \%, n=2145 ; p<0.001)$ and no significant difference between 2008 and $2017(p=0.919)$. Importantly, K65R showed a clear rise along the years (Figure 1). In 2008, the mutation was relatively rare and only found in $2.23 \%(n=8)$ of the population. Subsequently, this mutation became more prevalent and increased significantly between 2013 and $2015(p<0.001)$. Although its prevalence suffered a decrease between 2015 and $2016(p=0.0124)$, K65R prevailed the third most common SDRM in 2016 and 2017 (Figure 1). Overall, the data strongly supports that, in contrast with other prevalent SDRM, K65R prevalence was increasing in Brazil, raising additional concerns about the efficacy of some of the ART combinations used. In line with this hypothesis was the finding that viral loads for PLWH with K65R were significantly higher than for the rest of the cohort $(180,739.60 \pm 497,000.10 \mathrm{cop} / \mathrm{mL}$ vs. 95,358.26 $\pm 338,930.67 \mathrm{cop} / \mathrm{mL}$, respectively; $p<0.001)$.

Table 2. Yearly distribution of the most prevalent surveillance drug-resistance mutations in HIV-1 RT and PR.

\begin{tabular}{|c|c|c|c|c|c|c|c|c|c|c|}
\hline & 2008 & 2009 & 2010 & 2011 & 2012 & 2013 & 2014 & 2015 & 2016 & $2017^{* *}$ \\
\hline M184V & $276(76.88)$ & 416 (73.37) & 375 (75.45) & $1076(75.3)$ & $1781(72.46)$ & $2082(71.94)$ & $2004(69.58)$ & $1874(68.29)$ & $2684 *(53.21)$ & $697(51.48)$ \\
\hline $\mathrm{K} 103 \mathrm{~N}$ & $149(41.5)$ & $252(44.44)$ & 217 (43.66) & $638(44.65)$ & 1083 (44.06) & 1215 (41.98) & 1180 (40.97) & $1293 *(47.12)$ & $2145 *(42.53)$ & $566(41.8)$ \\
\hline M41L & $125(34.82)$ & $182(32.1)$ & 155 (31.19) & $383(26.8)$ & $561 *(22.28)$ & $585 *(20.21)$ & $425 *(14.76)$ & $374(13.63)$ & $545 *(10.8)$ & 145 (10.71) \\
\hline D67N & $114(31.75)$ & $163(28.75)$ & $149(29.98)$ & $337 *(23.58)$ & $504 *(20.5)$ & $487 *(16.83)$ & 435 (15.1) & 398 (14.5) & $526 *(10.43)$ & $140(10.34)$ \\
\hline T215Y & $109(30.36)$ & $144(25.4)$ & 141 (28.37) & $299 *(20.92)$ & $403 *(16.4)$ & $434(15)$ & $323 *(11.22)$ & 277 (10.09) & $336 *(6.66)$ & $72(5.32)$ \\
\hline K70R & $96(26.74)$ & $133(23.46)$ & 131 (26.36) & $308 *(21.55)$ & $451 *(18.35)$ & $459 *(15.86)$ & $368 *(12.78)$ & 344 (12.54) & $460 *(9.12)$ & 116 (8.57) \\
\hline V82A & $82(22.84)$ & 111 (19.58) & $91(18.31)$ & $206 *(14.42)$ & 335 (13.63) & $313 *(10.82)$ & $251 *(8.72)$ & $242(8.82)$ & $303 *(6.01)$ & $87(6.43)$ \\
\hline M46I & $81(22.56)$ & $122(21.52)$ & $89(17.91)$ & 207 (14.49) & 302 (12.29) & $302 *(10.44)$ & $222 *(7.71)$ & $207(7.54)$ & $324(6.42)$ & $82(6.06)$ \\
\hline L210W & $75(20.89)$ & $109(19.22)$ & $96(19.32)$ & $204 *(14.28)$ & $294 *(11.96)$ & $301(10.4)$ & $199 *(6.91)$ & $172(6.27)$ & $249 *(4.94)$ & $66(4.87)$ \\
\hline $\mathrm{I} 54 \mathrm{~V}$ & $73(20.33)$ & $115(20.28)$ & $79(15.9)$ & 191 (13.37) & $269 *(10.94)$ & $273(9.43)$ & $224 *(7.78)$ & 196 (7.14) & $241 *(4.78)$ & $58(4.28)$ \\
\hline G190A & $46(12.81)$ & $80(14.11)$ & $47 *(9.46)$ & $146(10.22)$ & $239(9.72)$ & $266(9.19)$ & $271(9.41)$ & $259(9.44)$ & $392 *(7.77)$ & $102(7.53)$ \\
\hline $\mathrm{P} 225 \mathrm{H}$ & $36(10.03)$ & $56(9.88)$ & 62 (12.47) & 179 (12.53) & 320 (13.02) & 403 (13.93) & 370 (12.85) & 390 (14.21) & $586 *(11.62)$ & 158 (11.67) \\
\hline K65R & $8(2.23)$ & $21(3.7)$ & $23(4.63)$ & $74(5.18)$ & $161(6.55)$ & $194(6.7)$ & $246 *(8.74)$ & $374 *(13.63)$ & $589 *(11.68)$ & $164(12.11)$ \\
\hline
\end{tabular}

Percentage number under parentheses. * A statistical difference was found with data from the previous year $(p<0.05)$. ${ }^{* *}$ Data for 2017 was only available Jan-Apr.

\subsection{A Shift on Treatment Scheme during the Years}

Having observed the clear increase in K65R along the studied yrs, we then decided to evaluate the ART combination schemes in use during the studied period (Figure 2), aiming at understanding ART usage impact on the SDRM. In 2008, from a total of 359 patients, the most prevalent ART combination was 3TC/AZT/EFV $(20.06 \%, n=72)$, followed by $3 \mathrm{TC} / \mathrm{AZT} / \mathrm{LPV}(8.36 \%, n=30)$, prevailing the most common treatment till $2014(25.03 \%$, $n=721$ ) among 2880 patients. From 2015 forward, 3TC/EFV/TDF scheme became the most prevalent. In this year $(n=2744), 24.85 \%$ (682) individuals were under 3TC/EFV/TDF drug combination and 19.97\% $(n=548)$ under 3TC/AZT/EFV. In 2017, 3TC/EFV/TDF combination was used on $40.10 \%(n=543)$ of the individuals on ART $(n=1354)$.

As we have found a shift on the ART treatment scheme during the studied years, we decided to evaluate SDRM prevalence separating the individuals using the most common drug combinations, 3TC/EFV/TDF $(21.38 \%, n=4324)$ and 3TC/AZT /EFV $(19.79 \%$, $n=4003$ ) (Figure 3 ). The SDRM with most similar prevalence when comparing both groups were M46I, V82A, L90M and I54V. In contrast, K65R was only found in $0.37 \%(n=15)$ of the viruses isolated from patients treated with 3TC/AZT/EFV vs. $30.64 \%(n=1325)$ of the viruses from individuals using 3TC/EFV/TDF. This strong association of K65R with TDF containing schemes was found across HIV-1 subtypes (Supplementary Figure S1). Focusing on 2015, the year where the number of patients $(n=2744)$ using the two schemes 
was more even (3TC/AZT/EFV: $19.97 \%, n=548$; vs. 3TC/EFV/TDF: $24.85 \%, n=682$ ), 5 patients $(0.91 \%)$ treated with 3TC/AZT/EFV were infected with a K65R mutant, being this number significantly different $(p<0.001)$ from the 267 patients $(39.15 \%)$ treated with $3 \mathrm{TC} / \mathrm{EFV} / \mathrm{TDF}$ combination. Also, comparing all patients revealed a significant association between 3TC/EFV/TDF and K65R $(p<0.001)$.

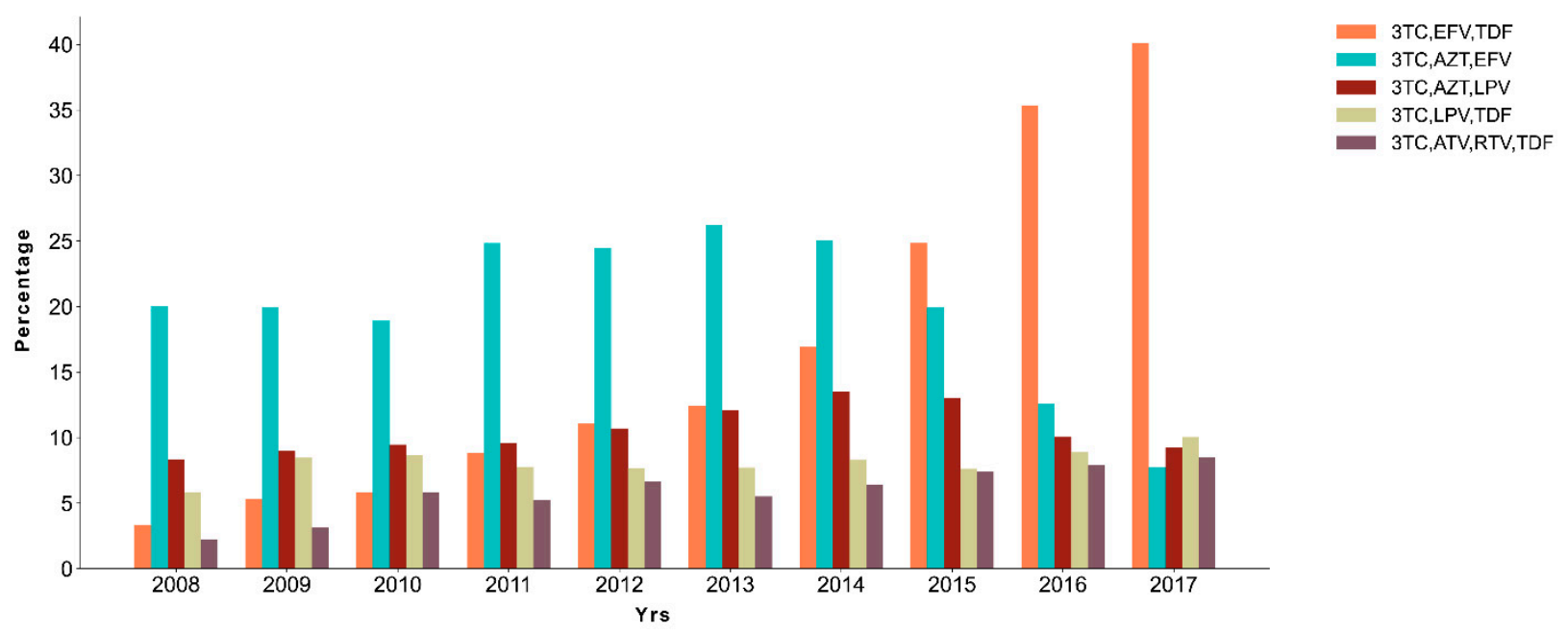

Figure 2. Treatment scheme used at time of viral sequencing between the yrs 2008 and 2017. Percentage of patients $(n=20,226)$ under the five more common ART combinations (3TC/EFV/TDF; 3TC/AZT/EFV; 3TC/AZT/LPV; $3 \mathrm{TC} / \mathrm{LPV} / \mathrm{TDF} ; 3 \mathrm{TC} / \mathrm{ATV} / \mathrm{RTV} / \mathrm{TDF}$ ) in the year of the viral sequencing.

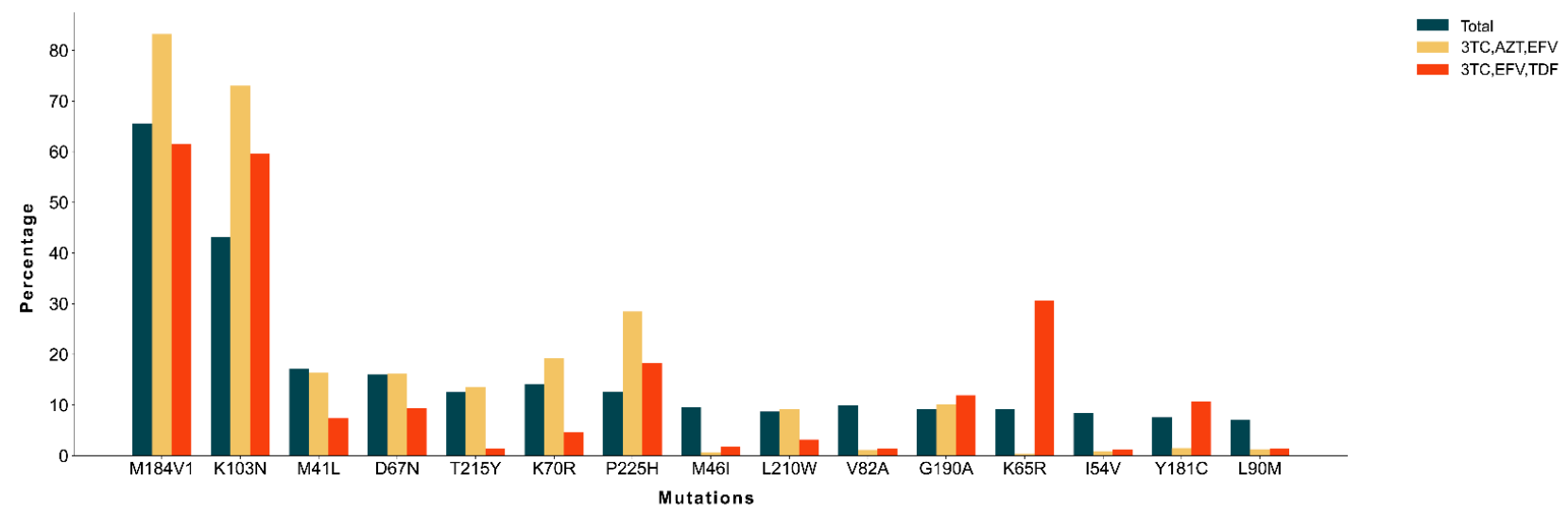

Figure 3. Most found SDRM by ART scheme. Percentage of individuals infected with viruses harboring common SDRM separated by ART scheme, discriminating 3TC/EFV /TDF $(n=4324$, orange), 3TC/AZT /EFV $(n=4003$, yellow $)$ and in the total of ART schemes.

\subsection{Evidence for Transmission of K65R}

To investigate if the transmission of virus harboring K65R could have contributed to the increase in the prevalence of this mutation in Brazil, we performed a phylogenetic analysis on a subset of viral sequences including all the sequences with the K65R mutation and closely related sequences from public databases (Supplementary Figures S2 and S3). The definition of transmission clusters was performed as previously [37] considering tree branch statistical support and mean genetic distance criteria. We found K65R in at least two HIV-1 sequences in 21 well-delimited transmission clusters (16 from subtype B and 5 from subtype C) (Supplementary Table S1). The size of the inferred transmission clusters ranged from three to 16 individuals. The minimum spanning network analysis of these clusters (Figure 4) supports the occurrence of events of K65R transmission in the study cohort. Furthermore, the analysis of the clinical records from the individuals likely involved in 
K65R transmission supports this possibility for several cases showing a coincidence of geographic location, proximity in diagnostic dates and similar reported transmission routes (Supplementary Table S1). Despite the significant increased prevalence of the K65R in subtype C $(11.26 \%, n=347)$ viruses when compared with B $(9.27 \%, n=1305)$ subtype $(p<0.001$, Supplementary Figure S2) we found probable events of K65R transmission also in subtype B viruses.

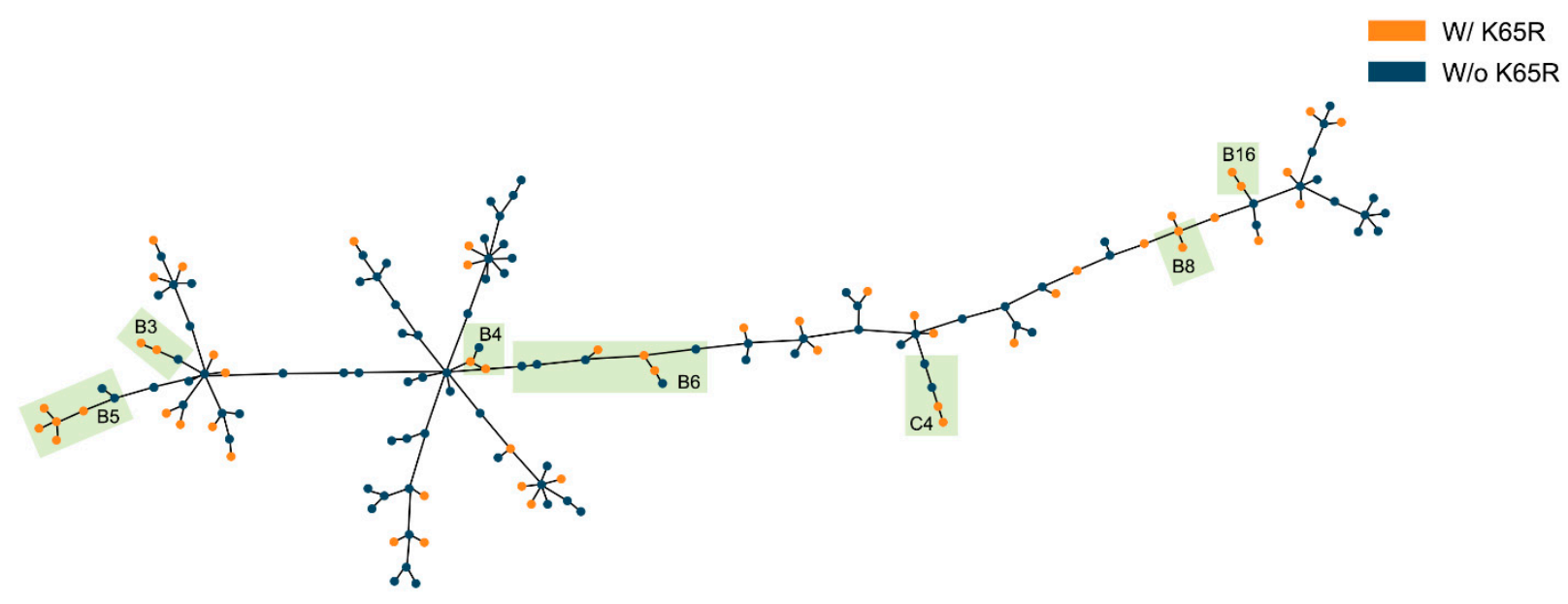

Figure 4. Minimum spanning network analysis of transmission clusters with more than one sequence with K65R mutation. Clusters compatible with K65R transmission are highlighted in green. Sequences without K65R mutation are marked in blue and in orange K65R mutants.

We then used an immunoinformatic approach to investigate the predicted impact of K65R on immune-driven selective pressures. We performed artificial neural networkbased predictions of binding to the globally most frequent class I HLAs of all the peptide sequences overlapping K65R and ranging from eight to 12 amino acids with the mutant or the wild-type residue. Interestingly, we found that K65R overlapping peptides were predicted to be recognized by two HLAs (HLA-A03, HLA-B58) in the wildtype version and by one additional HLA (HLA-B27) in the mutant version (Table 3). HLA-B27 has the lowest prevalence (2.23\%) in the Brazilian population of all the HLAs tested. Overall, our results suggest that the presence of K65R mutation might contribute for the immune control of the virus in individuals harboring HLA-B27 possibly decreasing its transmission in populations with high prevalence of this HLA.

Table 3. K65R mutant strong binding affinity to most frequent HLAs.

\begin{tabular}{lccc}
\hline & WT SB Binding & K65R SB Binding & Allele Freq. in BR Pop. \\
\hline HLA-A01 & no & no & 9.21 \\
HLA-A02 & no & no & 25.94 \\
HLA-A03 & yes & yes & 9.26 \\
HLA-A24 & no & no & 10.00 \\
HLA-A26 & no & no & 3.35 \\
HLA-B07 & no & no & 6.92 \\
HLA-B08 & no & no & 5.12 \\
HLA-B15 & no & no & 9.08 \\
HLA-B27 & no & yes & 2.23 \\
HLA-B39 & no & no & 3.46 \\
HLA-B40 & no & no & 4.70 \\
HLA-B58 & yes & yes & 2.65 \\
\hline
\end{tabular}




\section{Discussion}

Acquired and transmitted DRM remain one of the major obstacles towards ART efficacy and AIDS treatment. In case of Brazil, previous regional studies showed distinct moderate patters of transmitted DRM prevalence [11,16,20,27,38], and high DRM rates in patients receiving ART [17-19,27,39]. In this study, we aimed at understanding SDRM [26] prevalence across the 27 Brazilian federative units focusing on 20,226 HIV-1 infected patients under different ART schemes, with viral sequence genotyped between 2008 and 2017. In accordance to the Brazilian HIV-1 epidemiology report [36], our cohort was composed mainly by male individuals $(55.7 \%)$ and the majority of the patients' age varied between 30 and 49 years old (61.44\%).

A high prevalence of SDRM was observed with $84.1 \%$ of the infected individuals presenting at least one drug resistance mutation. Nonetheless, $68.5 \%$ of the genotyped sequences had a SDRM to NRTIs, a value that represents a decrease to what was previously reported in the literature [17-19,39,40], following a trend that has been described by Duani et al. and Diaz et al. in previous years [17,40]. However, NNRTI resistance rates $(57.95 \%)$ did not follow the increasing trend reported by the same authors, presenting a similar value to what has been found in previous works $[18,40]$. PI resistance mutations $(24.82 \%)$ also seem to follow the reported decreasing trend $[17,40]$.

Also in line with previous studies is the finding of M184V (65.53\%), $\mathrm{K} 103 \mathrm{~N}(40.20 \%)$, and M41L (17.21\%) as the most common SDRM [17,19,39,40]. M184V, the most prevalent, is a NRTI mutation selected by 3TC and associated with impaired viral fitness and hypersensitization to other NRTI, including AZT and TDF [41-43]. Along with the most common mutations, M184V rates presented a decrease over the yrs $(76.88 \%$ in 2008 to $51.48 \%$ in 2017). This decrease on acquired DRM was also observed in other countries and was hypothesized to be due to an improvement on treatment efficacy and also an increased accessibility to ART which enhances patient adherence to therapy [44-46]. Moreover, in Brazil, pretreatment genotyping has been extended to children living with HIV under 12 years of age, in case of $M t b$ co-infection, to pregnant woman and new diagnoses with a sexual partner on ART, since 2013 [47], which may had an impact the on the SDRM general decrease trend.

Nonetheless, it is important to highlight that the percentage of PLWH infected with a virus harboring M148V remained very high and above 50\% after 2013. Moreover, K103N and $\mathrm{P} 225 \mathrm{H}$, both frequent NNRTI SDRM, remained stable over the yrs. K103N was previously reported as one of the most commonly acquired SDRM in Brazil $[17,18,39,40]$ in association with the use of EFV [48]. P225H is also selected by EFV and generally occurs in the presence of $\mathrm{K} 103 \mathrm{~N}$, synergically increasing EFV resistance [48-50]. As for K65R, it is selected by TDF and by other NRTI including abacavir (ABC) and 3TC, decreasing viral susceptibility to most of these drugs $[29,31,51]$.

Previous work reported that K65R mutation presented varied prevalence distribution throughout time in different Brazilian regions [17,19,27]. Strikingly, in our nationwide work in Brazil we found that K65R was the only SDRM that followed an accentuated increase in prevalence over the studied years (2.23\% in 2008 to $12.11 \%$ in 2017). The increasing and preferential usage of TDF in the clinical practice [21], including in a context of a failing regimen, could be the primordial reason for the significant expansion of K65R as other studies show a higher prevalence of this mutation in patients failing ART treatment [15,52-55]. However, although an increasing trend was identified in a cohort from India [56], several studies report a decrease on K65R levels over the years in other countries [48,57-60]. Reinheimer and colleagues suggest that the decline on K65R prevalence rates is linked with the increasing usage of single tablet ART regimens and the inclusion of AZT on the used treatment regimen, which has been liked with K65R development suppression [61]. Moreover, Theys et al. work [59] suggests that the found decline of tenofovir K65R selection rate in Portugal, between 2002 and 2010, is mainly caused by changes on treatment guidelines over the years and by the increased usage of combination of TDF and emtricitabine (FTC) [59]. 
Collectively, these studies suggest that the genetic or sociodemographic characteristics of the population treated with TDF might be influencing the K65R levels.

In 2019, 15.074 individuals were reported to use PrEP in Brazil [1]. Although PrEP consists of a co-formulation of FTC and TDF [62], evidence suggests that the risk of selection for TDF resistance is low and is more likely to occur in cases of undiagnosed $\mathrm{HIV}$ infection $[63,64]$. However, in these cases, high prevalence rates of M184V, which is also selected by FTC, and K65R as found in our study population, might compromise the efficacy of PrEP $[65,66]$.

K65R has been associated with diminished viral fitness and replication, which has been linked with decreased transmission capacity [67,68]. Even though several studies support almost inexistent K65R transmission rates [11,69,70], Rhee and co-works present evidence of higher levels of transmitted K65R, especially in low- and middle-income countries [71]. In our phylogenetic analysis we found 21 transmission clusters containing at least two sequences with the K65R mutation. Moreover, minimum spanning network analysis supported the occurrence of events of K65R transmission in at least seven of these clusters. This might be suggestive that the efficacy of PrEP might be compromised in this setting. Indeed, we found much higher viral loads in patients harboring K65R mutation when compared with the rest of our cohort population. Similar viral loads were observed between individuals with and without tenofovir resistance by The TenoRes Study Group [72], which can be associated with increased mutation transmission. Furthermore, our results suggest that K65R overlapping peptides can be increasingly recognized by HLA-B27, a HLA that is linked with lower viral loads and slower diseased progression to AIDS [73,74]. The fact that Brazil presents a low prevalence of the HLA-B27, when in comparison with other regions [75-77], might have contributed to K65R expansion in this country. However, it is relevant to point-out that our results are based on in-silico prediction and not taking in consideration the possible impact on immune responses of the combination of different mutations in the same virus. Thus, it is relevant to address this topic in the future by performing functional studies.

Despite of the observed decreasing trend in the prevalence of some major SDRM in the studied Brazilian cohort, a high prevalence of these mutations was still verified. Indeed, our results show that the alteration performed in 2013 enlarging the criteria to include more PLWH in the recommendation for baseline SDRM testing had a positive impact but was still insufficient. We propose that the lack of universal baseline HIV-1 DRM screening to inform on effective ART regimens resulted in high levels of SDRM, such as M184V, K103N, and M41L underlying many cases of treatment failure in Brazil not only from 2008-2012 but also continuing from 2013-2017. Furthermore, we observed a clear increase in K65R reverse transcriptase SDRM that is an additional problem in Brazil that could have been aggravated by the circulation of HIV-1 subtype C and the HLA class I makeup of the population. This increase in K65R was mainly found in association with the use of TDF and is particularly relevant in combination with the high M184V levels found in the study population suggesting that the efficacy of PrEP might be compromised.

Overall, our results support that some of the drugs most frequently used in Brazil might be compromised due to the high frequency of SDRM and that baseline drug resistance testing should be universal and mandatory as it is the best way to promote personalized selection of the most optimized ART regiment.

\section{Materials and Methods}

\subsection{Study Population}

The collection of the patient's data was performed anonymously after approval by the Brazilian national ethic committee through the protocol CAAE 53757016.0.0000.5504. All records from HIV-1-infected individuals followed by the Specialized Assistance Services on Sexually Transmissible Diseases and HIV/AIDS obtained at all 27 Brazilian federative units from $01 / 01 / 2008$ to $04 / 30 / 2017$ were curated in a relational database. A total of 20,226 HIV-1 infected patients were selected for this study according to the following 
inclusion criteria: (i) be under ART treatment; (ii) have at least one associated partial HIV-1 genome sequence available (complete HIV protease $(n=20,223)$ and complete reverse transcriptase $(n=20,214))$. HIV-1 sequencing was performed as part of the routine clinical testing with commercially available HIV-1 genotyping systems based on Sanger sequencing.

\subsection{HIV-1 Subtypes and Drug Resistance Mutations}

HIV-1 subtypes were identified by relying on the consensus from least two of the three utilized subtyping tools: SNAPPY [78], jpHMM [79] and Stanford HIV Drug Resistance database (https:/ / hivdb.stanford.edu/, accessed on 1 May 2021). All sequences were also analyzed using the Stanford HIVdb Genotypic Resistance Interpretation Algorithm to evaluate and interpret the presence of DRM in each sequence.

\subsection{Phylogenetic Analysis of K65R Sequences and Transmission Clusters}

All sequences having the K65R were separated by subtype and used to query local and public databases to identify highly related HIV-1 sequences. The resulting sequences from the most common subtypes B and C were aligned with MAFFT v7.309 [80] and used to make a phylogenetic reconstruction using PhyML v3.0 [37]. The best fitting substitution model was GTR + G4 + I, determined by PhyML SMS using AIC [81]. The heuristic trees search was performed using SPR methods. Bayesian evolutionary analyses were performed using BEAST v1.10.4 [82,83] with GTR + G4 + I, as the nucleotide substitution model. This phylogenetic representation was used to infer the transmission clusters as previously [84]. Minimum spanning network analysis of the sequences identified in transmission clusters with more than one K65R mutant was performed with PHYLOViZ [85].

\subsection{HLA Binding Affinity Predictions}

Predictions of binding for different class 1 human leukocyte antigens (HLA) were performed with NetMHCpan 4.1 [86]. The wildtype sequence (NPYNTPVFAIKKKDSTKWRKLVD) and the sequence with the K65R mutation (NPYNTPVFAIKRKDSTKWRKLVD) were used to generate all possible peptides sequences overlapping position 65 and ranging from eight to 12 amino acids. A group of 11 HLAs were used as supertype representatives: HLA-A01:01; HLA-A02:01; HLA-A03:01; HLA-A24:02; HLA-A26:01; HLA-B07:02; HLAB08:01; HLA-B27:05; HLA-B39:01; HLA-B40:01; HLA-B58:01; HLA-B15:01. The thresholds for the definition of binding were maintained as the tool defaults, only binding results classified as "strong binding" were considered.

\subsection{HLA Prevalence in the Brazilian Population}

The Allele Frequencies Database [87] was used as the source of this information for the Brazilian population. To obtain cohesive and yet representative nationwide results, the bone marrow registry (REDOME) data was selected. Since this data is separated by Brazilian state, we calculated the proportional values for a national level estimation.

\subsection{Statistical Analysis}

Statistical analysis was performed by using Epi Info ${ }^{\mathrm{TM}}$ version 7.2.4.0 (https:/ / www. cdc.gov/epiinfo/index.html, accessed on 1 May 2021), relying on Mantel-Haenszel test, at significance level of 0.05 , to evaluate statistical correlations. SPSS ${ }^{\circledR}$ Statistics version 26.0 $\left(\mathrm{IBM}^{\circledR}\right.$, Armonk, NY, USA) was also utilized for performing mean comparison with t-test, at a 0.05 significance level.

Supplementary Materials: The following are available online at https: / www.mdpi.com/article / 10.3390/ijms22105304/s1, Figure S1: Presence of SDMR among subtypes, Figure S2: Phylogenetic representation of a subset of HIV-1 subtype C sequences isolated in Brazil with the K65R mutation and closely related sequences from databases, Figure S3: Phylogenetic representation of a subset of HIV-1 subtype B sequences isolated in Brazil with the K65R mutation and closely related sequences from databases. Table S1: Phylogeny inferred HIV-1 transmission clusters with more than one 
sequences harboring the K65R mutation, Table S2: Top SDRM on different Brazilian Regions through the years.

Author Contributions: A.S.-P., J.M., B.S., V.T., N.S.O. and P.M.M.A. analyzed data. E.P., H.S. and B.S. provided technical expertise for the work and insightful comments to the manuscript. A.S.-P. prepared the figures. N.S.O. designed the study. A.S.-P. and N.S.O. wrote the manuscript. All authors have read and agreed to the published version of the manuscript.

Funding: This work has been funded by Portuguese National funds, through the Foundation for Science and Technology (FCT) (project UIDB/50026/2020 and UIDP/50026/2020; by the projects NORTE-01-0145-FEDER-000013 and NORTE-01-0145-FEDER-000023, supported by Norte Portugal Regional Operational Programme (NORTE 2020), under the PORTUGAL 2020 Partnership Agreement, through the European Regional Development Fund (ERDF) and by Gilead Génese PGG/009/2017. ASP and PMMA were funded by FCT PhD scholarships PD/BD/127827/2016, and $\mathrm{PDE} / \mathrm{BDE} / 113599 / 2015$, respectively.

Institutional Review Board Statement: The study was conducted according to the guidelines of the Declaration of Helsinki and approved by the Brazilian National Ethics Committee through the protocol CAAE 53757016.0.0000.5504.

Informed Consent Statement: Patient consent was waived since all data was anonymous and collected retrospectively.

Data Availability Statement: The HIV-1 sequences selected for this study were made available in GenBank (accession numbers will be included here).

Acknowledgments: We acknowledge all the health care and administrative professional involved in the collection of data and sequencing of the samples in the health-care centers followed by Specialized Assistance Services on Sexually Transmissible Diseases and HIV / AIDS of Brazil. We also thank the Brazilian Health Ministry for implementing exemplar digital platforms for centralization of national clinical data and ethical regulation that promote biomedical research. Moreover, we would like to thank Juliana Monteiro da Cruz from the Department of Surveillance, Prevention and Control of Sexually Transmitted Infections, HIV / AIDS and Viral Hepatitis, Secretariat of Health Surveillance, Ministry of Health (Brazil), for her large commitment and availability in the administrative processes to access the clinical data used in this study.

Conflicts of Interest: The authors declare no conflict of interest.

\section{References}

1. Joint United Nations Programme on HIV/AIDS. UNAIDS Data 2020; UNAIDS: Geneva, Switzerland, 2020.

2. Souza, P.R.B.D., Jr.; Szwarcwald, C.L.; Castilho, E.A.D. Self-rated health by HIV-infected individuals undergoing antiretroviral therapy in Brazil. Cad. Saúde Pública/Ministério Saúde, Fundação Oswaldo Cruz. Esc. Nac. Saúde Pública 2011. [CrossRef]

3. Teeraananchai, S.; Kerr, S.J.; Amin, J.; Ruxrungtham, K.; Law, M.G. Life expectancy of HIV-positive people after starting combination antiretroviral therapy: A meta-analysis. HIV Med. 2017, 18, 256-266. [CrossRef]

4. Trickey, A.; May, M.T.; Vehreschild, J.J.; Obel, N.; Gill, M.J.; Crane, H.M.; Boesecke, C.; Patterson, S.; Grabar, S.; Cazanave, C.; et al. Survival of HIV-positive patients starting antiretroviral therapy between 1996 and 2013: A collaborative analysis of cohort studies. Lancet HIV 2017, 4, e349-e356. [CrossRef]

5. Saag, M.S.; Gandhi, R.T.; Hoy, J.F.; Landovitz, R.J.; Thompson, M.A.; Sax, P.E.; Smith, D.M.; Benson, C.A.; Buchbinder, S.P.; Del Rio, C.; et al. Antiretroviral Drugs for Treatment and Prevention of HIV Infection in Adults: 2020 Recommendations of the International Antiviral Society-USA Panel. JAMA 2020, 324, 1651-1669. [CrossRef]

6. Lundgren, J.; Phillips, A. Prevention of HIV transmission by antiretroviral therapy. Lancet HIV 2018, 5, e108-e109. [CrossRef]

7. Eisinger, R.W.; Dieffenbach, C.W.; Fauci, A.S. HIV viral load and transmissibility of HIV infection undetectable equals untransmittable. JAMA 2019, 321, 451-452. [CrossRef]

8. Cohen, M.S.; Chen, Y.Q.; McCauley, M.; Gamble, T.; Hosseinipour, M.C.; Kumarasamy, N.; Hakim, J.G.; Kumwenda, J.; Grinsztejn, B.; Pilotto, J.H.S.; et al. Antiretroviral Therapy for the Prevention of HIV-1 Transmission. N. Engl. J. Med. 2016, 375, 830-839. [CrossRef] [PubMed]

9. Tanaka, T.S.O.; Leite, T.F.; Freitas, S.Z.; Cesar, G.A.; De Rezende, G.R.; Lindenberg, A.D.S.C.; Guimarães, M.L.; Motta-Castro, A.R.C. HIV-1 molecular epidemiology, transmission clusters and transmitted drug resistance mutations in central Brazil. Front. Microbiol. 2019, 10. [CrossRef]

10. Booth, C.L.; Geretti, A.M. Prevalence and determinants of transmitted antiretroviral drug resistance in HIV-1 infection. J. Antimicrob. Chemother. 2007, 59, 1047-1056. [CrossRef] 
11. Arruda, M.B.; Boullosa, L.T.; Cardoso, C.C.; da Costa, C.M.; Brites, C.; de Lima, S.T.S.; Kaminski, H.T.; Aleixo, A.W.; Esposito, A.O.P.; Cavalcanti, A.M.S.; et al. Brazilian network for HIV drug resistance surveillance (HIV-BresNet): A survey of treatmentnaive individuals. J. Int. AIDS Soc. 2018, 21. [CrossRef]

12. Geretti, A.M. Epidemiology of antiretroviral drug resistance in drug-naïve persons. Curr. Opin. Infect. Dis. 2007, $20,22-32$. [CrossRef] [PubMed]

13. Frentz, D.; Boucher, C.A.B.; Van De Vijver, D.A.M.C. Temporal changes in the epidemiology of transmission of drug-resistant HIV-1 across the world. AIDS Rev. 2012, 14, 17-27.

14. Sui, H.; Gui, T.; Jia, L.; Guo, W.; Han, J.; Liu, Y.; Bao, Z.; Li, H.; Li, J.; Li, L. Different Frequencies of Drug Resistance Mutations among HIV-1 Subtypes Circulating in China: A Comprehensive Study. PLoS ONE 2014, 9, e91803. [CrossRef]

15. Chaplin, B.; Eisen, G.; Idoko, J.; Onwujekwe, D.; Idigbe, E.; Adewole, I.; Gashau, W.; Meloni, S.; Sarr, A.D.; Sankalé, J.L.; et al. Impact of HIV type 1 subtype on drug resistance mutations in Nigerian patients failing first-line therapy. AIDS Res. Hum. Retrovir. 2011, 27, 71-80. [CrossRef] [PubMed]

16. Bahls, L.D.; Canezin, P.H.; Reiche, E.M.V.; Fernandez, J.C.C.; Dias, J.R.C.; Meneguetti, V.A.F.; Ueda, L.T.; Bertolini, D.A. Moderate prevalence of HIV-1 transmitted drug resistance mutations in southern Brazil. AIDS Res. Ther. 2019. [CrossRef] [PubMed]

17. Duani, H.; Aleixo, A.W.; Tupinambás, U. Trends and predictors of HIV-1 acquired drug resistance in Minas Gerais, Brazil: 2002-2012. Braz. J. Infect. Dis. 2017, 21, 148-154. [CrossRef] [PubMed]

18. Cavalcanti, A.M.S.; Lacerda, H.R.; De Brito, A.M.; Pereira, S.; Medeiros, D.; Oliveira, S. Antiretroviral resistance in individuals presenting therapeutic failure and subtypes of the human immunodeficiency virus type 1 in the Northeast Region of Brazil. Mem. Inst. Oswaldo Cruz 2007, 102, 785-792. [CrossRef]

19. Toledo, P.V.M.; de Carvalho, D.S.; Romagnoli, L.; Marcinko, G.; da Cunha, C.A.; de Souza, M.N.; Brindeiro, R.; de Queiroz-Telles, F. HIV-1 genotypic resistance profile of patients failing antiretroviral therapy in Paraná, Brazil. Braz. J. Infect. Dis. 2010, 14, 360-371. [CrossRef]

20. Coelho, L.P.O.; Matsuda, E.M.; Nogueira, R.S.; de Moraes, M.J.; Jamal, L.F.; Madruga, J.V.R.; Tancredi, M.V.; de Leão, A.C.Q.; de Faria Romero Soldi, G.; de Macedo Brígido, L.F.; et al. Prevalence of HIV-1 transmitted drug resistance and viral suppression among recently diagnosed adults in São Paulo, Brazil. Arch. Virol. 2019, 164, 699-706. [CrossRef]

21. Ministério da Saúde. Clinical Protocol and Therapeutic Guidelines for Handling HIV Infection in Adults, 1st ed.; Ministério da Saúde, Secretaria de Vigilância em Saúde, Departamento de Vigilância, Prevenção e Controle das Infecções Sexualmente Transmissíveis, do HIV / Aids e das Hepatites Virais: Brasilia, Brazil, 2018; ISBN 9788533426436.

22. Benzaken, A.S.; Pereira, G.F.M.; Costa, L.; Tanuri, A.; Santos, A.F.; Soares, M.A. Antiretroviral treatment, government policy and economy of HIV / AIDS in Brazil: Is it time for HIV cure in the country? AIDS Res. Ther. 2019, 16. [CrossRef]

23. European AIDS Clinical Society. European AIDS clinical society guidelines. Version 10.0. November 2019. IEEE Trans. Sonics Ultrason. 2019, 6-11.

24. Panel on Antiretroviral Guidelines for Adults and Adolescents Guidelines for the Use of Antiretroviral Agents in Adults and Adolescents with HIV. Department of Health and Human Services. Available online: https: / / clinicalinfo.hiv.gov/sites/default/ files/guidelines/documents/AdultandAdolescentGL.pdf (accessed on 18 May 2021).

25. Günthard, H.F.; Calvez, V.; Paredes, R.; Pillay, D.; Shafer, R.W.; Wensing, A.M.; Jacobsen, D.M.; Richman, D.D. Human Immunodeficiency Virus Drug Resistance: 2018 Recommendations of the International Antiviral Society-USA Panel. Clin. Infect. Dis. 2019, 68, 177-187. [CrossRef] [PubMed]

26. Bennett, D.E.; Camacho, R.J.; Otelea, D.; Kuritzkes, D.R.; Fleury, H.; Kiuchi, M.; Heneine, W.; Kantor, R.; Jordan, M.R.; Schapiro, J.M.; et al. Drug Resistance Mutations for Surveillance of Transmitted HIV-1 Drug-Resistance: 2009 Update. PLoS ONE 2009, 4, e4724. [CrossRef] [PubMed]

27. Brites, C.; Pinto-Neto, L.; Medeiros, M.; Nunes, E.; Sprinz, E.; Carvalho, M. Extensive variation in drug-resistance mutational profile of Brazilian patients failing antiretroviral therapy in five large Brazilian cities. Braz. J. Infect. Dis. 2016, 20, 323-329. [CrossRef]

28. Touloumi, G.; Pantazis, N.; Pillay, D.; Paraskevis, D.; Chaix, M.-L.; Bucher, H.C.; Kucherer, C.; Zangerle, R.; Kran, A.-M.B.; Porter, K.; et al. Impact of HIV-1 Subtype on CD4 Count at HIV Seroconversion, Rate of Decline, and Viral Load Set Point in European Seroconverter Cohorts. Clin. Infect. Dis. 2013, 56, 888-897. [CrossRef]

29. Wensing, A.M.; Calvez, V.; Ceccherini-Silberstein, F.; Charpentier, C.; Günthard, H.F.; Paredes, R.; Shafer, R.W.; Richman, D.D. 2019 update of the drug resistance mutations in HIV-1. Top. Antivir. Med. 2019, 27, 111-121.

30. White, K.L.; Chen, J.M.; Feng, J.Y.; Margot, N.A.; Ly, J.K.; Ray, A.S.; Macarthur, H.L.; McDermott, M.J.; Swaminathan, S.; Miller, M.D. The K65R reverse transcriptase mutation in HIV-1 reverses the excision phenotype of zidovudine resistance mutations. Antivir. Ther. 2006, 11, 155-163.

31. Brenner, B.G.; Coutsinos, D. The K65R mutation in HIV-1 reverse transcriptase: Genetic barriers, resistance profile and clinical implications. HIV Ther. 2009, 3, 583-594. [CrossRef]

32. Smit, E.; White, E.; Clark, D.; Churchill, D.; Zhang, H.; Collins, S.; Pillay, D.; Sabin, C.; Nelson, M.; Winston, A.; et al. An association between K65R and HIV-1 subtype C viruses in patients treated with multiple NRTIs. J. Antimicrob. Chemother. 2017, 72, 2075-2082. [CrossRef] 
33. Inzaule, S.C.; Weidle, P.J.; Yang, C.; Ndiege, K.; Hamers, R.L.; Rinke de Wit, T.F.; Thomas, T.; Zeh, C. Prevalence and dynamics of the K65R drug resistance mutation in HIV-1-infected infants exposed to maternal therapy with lamivudine, zidovudine and either nevirapine or nelfinavir in breast milk. J. Antimicrob. Chemother. 2016, 71, 1619-1626. [CrossRef]

34. Theys, K.; Vercauteren, J.; Snoeck, J.; Zazzi, M.; Camacho, R.J.; Torti, C.; Schülter, E.; Clotet, B.; Sönnerborg, A.; De Luca, A.; et al. HIV-1 subtype is an independent predictor of reverse transcriptase mutation k65r in HIV-1 patients treated with combination antiretroviral therapy including tenofovir. Antimicrob. Agents Chemother. 2013, 57, 1053-1056. [CrossRef] [PubMed]

35. Coutsinos, D.; Invernizzi, C.F.; Moisi, D.; Oliveira, M.; Martinez-Cajas, J.L.; Brenner, B.G.; Wainberg, M.A. A Template-Dependent Dislocation Mechanism Potentiates K65R Reverse Transcriptase Mutation Development in Subtype C Variants of HIV-1. PLoS ONE 2011, 6, e20208. [CrossRef] [PubMed]

36. Ministério da Saúde. Boletim Epidemiológico de HIV e Aids; Ministério da Saúde Secretaria de Vigilância em Saúde Departamento de Vigilância, Prevenção e Controle das Infecções Sexualmente Transmissíveis, do HIV/Aids e das Hepatites Virais: Brasilia, Brazil, 2018; ISBN 1517-1159.

37. Guindon, S.; Dufayard, J.-F.; Lefort, V.; Anisimova, M.; Hordijk, W.; Gascuel, O. New Algorithms and Methods to Estimate Maximum-Likelihood Phylogenies: Assessing the Performance of PhyML 3.0. Syst. Biol. 2010, 59, 307-321. [CrossRef] [PubMed]

38. Sprinz, E.; Netto, E.M.; Lima, M.P.J.S.; Furtado, J.J.D.; Da Eira, M.; Zajdenverg, R.; Madruga, J.V.; Lewi, D.S.; Pedro, R.J.; Soares, M.A. Primary antiretroviral drug resistance among HIV Type 1-infected individuals in Brazil. AIDS Res. Hum. Retrovir. 2009, 25, 861-867. [CrossRef] [PubMed]

39. Lopes, C.A.F.; Soares, M.A.; Falci, D.R.; Sprinz, E. The Evolving Genotypic Profile of HIV-1 Mutations Related to Antiretroviral Treatment in the North Region of Brazil. Biomed. Res. Int. 2015, 2015. [CrossRef]

40. Diaz, R.S.; Inocêncio, L.A.; Sucupira, M.C.A.; Pereira, A.A.; Hunter, J.; Ferreira, J.E.; Araújo, L.V.; Souza, D.F.C.; Sabino, E.C. The Virological and Immunological Characteristics of the HIV-1-Infected Population in Brazil: From Initial Diagnosis to Impact of Antiretroviral Use. PLoS ONE 2015, 10, e0139677. [CrossRef]

41. Wolf, K.; Walter, H.; Beerenwinkel, N.; Keulen, W.; Kaiser, R.; Hoffmann, D.; Lengauer, T.; Selbig, J.; Vandamme, A.M.; Korn, K.; et al. Tenofovir Resistance and Resensitization. Antimicrob. Agents Chemother. 2003, 47, 3478-3484. [CrossRef]

42. Götte, M.; Arion, D.; Parniak, M.A.; Wainberg, M.A. The M184V Mutation in the Reverse Transcriptase of Human Immunodeficiency Virus Type 1 Impairs Rescue of Chain-Terminated DNA Synthesis. J. Virol. 2000, 74, 3579-3585. [CrossRef]

43. Turner, D.; Brenner, B.G.; Routy, J.P.; Petrella, M.; Wainberg, M.A. Rationale for maintenance of the M184v resistance mutation in human immunodeficiency virus type 1 reverse transcriptase in treatment experienced patients. New Microbiol. 2004, $27,31-39$.

44. Pingarilho, M.; Pimentel, V.; Diogo, I.; Fernandes, S.; Miranda, M.; Pineda-Pena, A.; Libin, P.; Theys, K.; Martins, M.R.O.; Vandamme, A.M.; et al. Increasing Prevalence of HIV-1 Transmitted Drug Resistance in Portugal: Implications for First Line Treatment Recommendations. Viruses 2020, 12, 1238. [CrossRef] [PubMed]

45. Franzetti, M.; Violin, M.; Antinori, A.; De Luca, A.; Ceccherini-Silberstein, F.; Gianotti, N.; Torti, C.; Bonora, S.; Zazzi, M.; Balotta, C. Trends and correlates of HIV-1 resistance among subjects failing an antiretroviral treatment over the 2003-2012 decade in Italy. BMC Infect. Dis. 2014, 14, 398. [CrossRef]

46. Rocheleau, G.; Brumme, C.J.; Shoveller, J.; Lima, V.D.; Harrigan, P.R. Longitudinal trends of HIV drug resistance in a large Canadian cohort, 1996-2016. Clin. Microbiol. Infect. 2018, 24, 185-191. [CrossRef] [PubMed]

47. Ministério da Saúde. Protocolo Clínico E Diretrizes Terapêtuicas Para O Manejo Da Infecção Pelo HIV; Ministério da Saúde Secretaria de Vigilância em Saúde Departamento de Vigilância, Prevenção e Controle das Infecções Sexualmente Transmissíveis, do HIV/Aids e das Hepatites Virais: Brasilia, Brazil, 2013.

48. Bacheler, L.T.; Anton, E.D.; Kudish, P.; Baker, D.; Bunville, J.; Krakowski, K.; Bolling, L.; Aujay, M.; Wang, X.V.; Ellis, D.; et al. Human immunodeficiency virus type 1 mutations selected in patients failing efavirenz combination therapy. Antimicrob. Agents Chemother. 2000, 44, 2475-2484. [CrossRef] [PubMed]

49. Alcaro, S.; Alteri, C.; Artese, A.; Ceccherini-Silberstein, F.; Costa, G.; Ortuso, F.; Bertoli, A.; Forbici, F.; Santoro, M.M.; Parrotta, L.; et al. Docking Analysis and Resistance Evaluation of Clinically Relevant Mutations Associated with the HIV-1 Non-nucleoside Reverse Transcriptase Inhibitors Nevirapine, Efavirenz and Etravirine. Chem. Med. Chem. 2011, 6, 2203-2213. [CrossRef] [PubMed]

50. Bacheler, L.; Jeffrey, S.; Hanna, G.; D'Aquila, R.; Wallace, L.; Logue, K.; Cordova, B.; Hertogs, K.; Larder, B.; Buckery, R.; et al. Genotypic Correlates of Phenotypic Resistance to Efavirenz in Virus Isolates from Patients Failing Nonnucleoside Reverse Transcriptase Inhibitor Therapy. J. Virol. 2001, 75, 4999-5008. [CrossRef]

51. Garforth, S.J.; Lwatula, C.; Prasad, V.R. The lysine 65 residue in HIV-1 reverse transcriptase function and in nucleoside analog drug resistance. Viruses 2014, 6, 4080-4094. [CrossRef]

52. Ayitewala, A.; Kyeyune, F.; Ainembabazi, P.; Nabulime, E.; Kato, C.D.; Nankya, I. Comparison of HIV drug resistance profiles across HIV-1 subtypes A and D for patients receiving a tenofovir-based and zidovudine-based first line regimens in Uganda. AIDS Res. Ther. 2020, 17. [CrossRef]

53. Luo, X.L.; Mo, L.D.; Su, G.S.; Huang, J.P.; Wu, J.Y.; Su, H.Z.; Huang, W.H.; Luo, S.D.; Ni, Z.Y. Incidence and types of HIV-1 drug resistance mutation among patients failing first-line antiretroviral therapy. J. Pharmacol. Sci. 2019, 139, 275-279. [CrossRef]

54. Parker Hudson, F.; Mulenga, L.; Westfall, A.O.; Warrier, R.; Mweemba, A.; Saag, M.S.; Stringer, J.S.A.; Eron, J.J.; Chi, B.H. Evolution of HIV-1 drug resistance after virological failure of first-line antiretroviral therapy in Lusaka, Zambia. Antivir. Ther. 2019, 24, 291-300. [CrossRef] 
55. Van Zyl, G.U.; Liu, T.F.; Claassen, M.; Engelbrecht, S.; de Oliveira, T.; Preiser, W.; Wood, N.T.; Travers, S.; Shafer, R.W. Trends in Genotypic HIV-1 Antiretroviral Resistance between 2006 and 2012 in South African Patients Receiving First-and Second-Line Antiretroviral Treatment Regimens. PLoS ONE 2013, 8, e67188. [CrossRef]

56. Karade, S.; Chaturbhuj, D.N.; Sen, S.; Joshi, R.K.; Kulkarni, S.S.; Shankar, S.; Gangakhedkar, R.R. HIV drug resistance following a decade of the free antiretroviral therapy programme in India: A review. Int. J. Infect. Dis. 2018, 66, 33-41. [CrossRef] [PubMed]

57. Tittle, V.; Boffito, M.; McOwan, A.; Whitlock, G. Antiretroviral resistance and management after pre-exposure to prophylaxis. Lancet HIV 2020, 7, e84. [CrossRef]

58. Charpentier, C.; Lambert-Niclot, S.; Visseaux, B.; Morand-Joubert, L.; Storto, A.; Larrouy, L.; Landman, R.; Calvez, V.; Marcelin, A.-G.; Descamps, D. Evolution of the K65R, K103N and M184V/I reverse transcriptase mutations in HIV-1-infected patients experiencing virological failure between 2005 and 2010. J. Antimicrob. Chemother. 2013, 68, 2197-2198. [CrossRef] [PubMed]

59. Theys, K.; Snoeck, J.; Vercauteren, J.; Abecasis, A.B.; Vandamme, A.M.; Camacho, R.J.; Mansinho, K.; Miranda, A.C.; Aldir I.; Ventura, F.; et al. Decreasing population selection rates of resistance mutation K65R over time in HIV-1 patients receiving combination therapy including tenofovir. J. Antimicrob. Chemother. 2013, 68, 419-423. [CrossRef] [PubMed]

60. Dolling, D.; Sabin, C.; Delpech, V.; Smit, E.; Pozniak, A.; Asboe, D.; Brown, A.L.; Churchill, D.; Williams, I.; Geretti, A.M.; et al. Time trends in drug resistant HIV-1 infections in the United Kingdom up to 2009: Multicentre observational study. BMJ 2012, 345. [CrossRef]

61. Reinheimer, C.; Wesner, A.; Keppler, O.T.; Doerr, H.W.; Herrmann, E.; Stürmer, M.; Stephan, C. Prevalence of K65R in patients treated with tenofovir disoproxil fumarate: Recommendations based on the Frankfurt HIV Cohort Study Resistance Database (FHCS-RD). Med. Microbiol. Immunol. 2016, 205, 315-320. [CrossRef]

62. Ministério da Saúde. Protocolo Clínico E Diretrizes Terapêuticas Para Profilaxia Pré-Exposição (Prep) De Risco À Infeç̧ão Pelo HIV, 1st ed.; Ministério da Saúde Secretaria de Vigilância em Saúde Departamento de Vigilância, Prevenção e Controle das Infecções Sexualmente Transmissíveis, do HIV/Aids e das Hepatites Virais: Brasilia, Brazil, 2018; Volume 29, ISBN 978-85-334-2582-8.

63. Gibas, K.M.; van den Berg, P.; Powell, V.E.; Krakower, D.S. Drug Resistance During HIV Pre-Exposure Prophylaxis. Drugs 2019, 79, 609-619. [CrossRef]

64. Parikh, U.M.; Mellors, J.W. Should we fear resistance from tenofovir/emtricitabine preexposure prophylaxis? Curr. Opin. HIV AIDS 2016, 11, 49-55. [CrossRef]

65. Margot, N.A.; Waters, J.M.; Miller, M.D. In vitro human immunodeficiency virus type 1 resistance selections with combinations of tenofovir and emtricitabine or abacavir and lamivudine. Antimicrob. Agents Chemother. 2006, 50, 4087-4095. [CrossRef]

66. Diallo, K.; Götte, M.; Wainberg, M.A. Molecular impact of the M184V mutation in human immunodeficiency virus type 1 reverse transcriptase. Antimicrob. Agents Chemother. 2003, 47, 3377-3383. [CrossRef]

67. Wagner, B.G.; Garcia-Lerma, J.G.; Blower, S. Factors limiting the transmission of HIV mutations conferring drug resistance: Fitness costs and genetic bottlenecks. Sci. Rep. 2012, 2. [CrossRef]

68. Weber, J.; Chakraborty, B.; Weberova, J.; Miller, M.D.; Quiñones-Mateu, M.E. Diminished replicative fitness of primary human immunodeficiency virus type 1 isolates harboring the K65R mutation. J. Clin. Microbiol. 2005, 43, 1395-1400. [CrossRef] [PubMed]

69. Chan, P.A.; Huang, A.; Kantor, R. Low prevalence of transmitted K65R and other tenofovir resistance mutations across different HIV-1 subtypes: Implications for pre-exposure prophylaxis. J. Int. AIDS Soc. 2012, 15. [CrossRef] [PubMed]

70. Margot, N.A.; Wong, P.; Kulkarni, R.; White, K.; Porter, D.; Abram, M.E.; Callebaut, C.; Miller, M.D. Commonly transmitted HIV-1 drug resistance mutations in reverse-transcriptase and protease in antiretroviral treatment-naive patients and response to regimens containing tenofovir disoproxil fumarate or tenofovir alafenamide. J. Infect. Dis. 2017, 215, 920-927. [CrossRef] [PubMed]

71. Rhee, S.Y.; Jordan, M.R.; Raizes, E.; Chua, A.; Parkin, N.; Kantor, R.; Van Zy, G.U.; Mukui, I.; Hosseinipour, M.C.; Frenkel, L.M.; et al. HIV-1 drug resistance mutations: Potential applications for point-of-care Genotypic resistance testing. PLoS ONE 2015, 10, e145772. [CrossRef]

72. Gregson, J.; Tang, M.; Ndembi, N.; Hamers, R.L.; Marconi, V.C.; Brooks, K.; Theys, K.; Arruda, M.; Garcia, F.; Monge, S.; et al. Global epidemiology of drug resistance after failure of WHO recommended first-line regimens for adult HIV-1 infection: A multicentre retrospective cohort study. Lancet Infect. Dis. 2016, 16, 565-575. [CrossRef]

73. Kløverpris, H.N.; Leslie, A.; Goulder, P. Role of HLA adaptation in HIV evolution. Front. Immunol. 2016, 6, 665. [CrossRef]

74. Neumann-Haefelin, C. HLA-B27-mediated protection in HIV and hepatitis C virus infection and pathogenesis in spondyloarthritis: Two sides of the same coin? Curr. Opin. Rheumatol. 2013, 25, 426-433. [CrossRef]

75. Roberts, R.L.; Wallace, M.C.; Jones, G.T.; van Rij, A.M.; Merriman, T.R.; Harrison, A.; White, D.; Stamp, L.K.; Ching, D.; Highton, J.; et al. Prevalence of HLA-B27 in the New Zealand population: Effect of age and ethnicity. Arthritis Res. Ther. 2013, 15, R158. [CrossRef]

76. Reveille, J.D.; Hirsch, R.; Dillon, C.F.; Carroll, M.D.; Weisman, M.H. The prevalence of HLA-B27 in the US: Data from the US National Health and Nutrition Examination Survey, 2009. Arthritis Rheum. 2012, 64, 1407-1411. [CrossRef]

77. Khan, M.A. HLA-B27 and its subtypes in world populations: Editorial review. Curr. Opin. Rheumatol. 1995, 7, 263-269. [CrossRef]

78. Araújo, P.M.M.; Martins, J.S.; Osório, N.S. SNAPPy: A snakemake pipeline for scalable HIV-1 subtyping by phylogenetic pairing. Virus Evol. 2019, 5. [CrossRef] [PubMed]

79. Schultz, A.K.; Zhang, M.; Bulla, I.; Leitner, T.; Korber, B.; Morgenstern, B.; Stanke, M. jpHMM: Improving the reliability of recombination prediction in HIV-1. Nucleic Acids Res. 2009, 37, 647-651. [CrossRef] 
80. Katoh, K.; Standley, D.M. MAFFT multiple sequence alignment software version 7: Improvements in performance and usability. Mol. Biol. Evol. 2013. [CrossRef]

81. Lefort, V.; Longueville, J.E.; Gascuel, O. SMS: Smart Model Selection in PhyML. Mol. Biol. Evol. 2017, 34, 2422-2424. [CrossRef]

82. Drummond, A.J.; Suchard, M.A.; Xie, D.; Rambaut, A. Bayesian phylogenetics with BEAUti and the BEAST 1.7. Mol. Biol. Evol. 2012, 29, 1969-1973. [CrossRef] [PubMed]

83. Ferreira, M.A.R.; Suchard, M.A. Bayesian analysis of elapsed times in continuous-time Markov chains. Can. J. Stat. 2008, 36, 355-368. [CrossRef]

84. Araújo, P.M.M.; Carvalho, A.; Pingarilho, M.; Abecasis, A.B.; Osório, N.S. Characterization of a large cluster of HIV-1 A1 infections detected in Portugal and connected to several Western European countries. Sci. Rep. 2019, 9, 7223. [CrossRef] [PubMed]

85. Ribeiro-Gonçalves, B.; Francisco, A.P.; Vaz, C.; Ramirez, M.; Carriço, J.A. PHYLOViZ Online: Web-based tool for visualization, phylogenetic inference, analysis and sharing of minimum spanning trees. Nucleic Acids Res. 2016, 44, W246-W251. [CrossRef]

86. Reynisson, B.; Alvarez, B.; Paul, S.; Peters, B.; Nielsen, M. NetMHCpan-4.1 and NetMHCIIpan-4.0: Improved predictions of MHC antigen presentation by concurrent motif deconvolution and integration of MS MHC eluted ligand data. Nucleic Acids Res. 2020, 48, W449-W454. [CrossRef]

87. Gonzalez-Galarza, F.F.; McCabe, A.; dos Santos, E.J.M.; Jones, J.; Takeshita, L.; Ortega-Rivera, N.D.; Cid-Pavon, G.M.D.; Ramsbottom, K.; Ghattaoraya, G.; Alfirevic, A.; et al. Allele frequency net database (AFND) 2020 update: Gold-standard data classification, open access genotype data and new query tools. Nucleic Acids Res. 2020, 48, D783-D788. [CrossRef] [PubMed] 